\title{
Masjid-Based Community Economic Empowerment
}

\author{
Ahmad Mu' is \\ Yuliati \\ Lailatul Farida
}

\begin{abstract}
Social Empowerment in rural society of Malang Village or local economic base on Masjid is community dedication configuration. This place has potential capital field and human resources development. The job of community majority are farmers. The field has been planted by holticulture variety while human resourses are religious community. The weaknesss are knowledge and ability to develop their village. The struggle of this empowerment is giving technical knowledge and skill of economic basic, for instance management, accounting and marketing. The methode of this researh is base on participation action research (PAR) in order to get deep information and participation from rural society. Masjid as fundamental factor to motivate and guide them to better human.
\end{abstract}

Keywords: Empowerment, Community Economic, Masjid

\section{INTRODUCTION}

The masjid or mosque is a means of empowering people who have a strategic role in improving the quality of society. When viewed from its function, the mosque is not only a place or facility for mahdloh worship activities, such as prayer and recitation, but the mosque can also function as a center for empowering various aspects of community life. Besides that history has explained, that is the era of Rosululloh, Muhammad SAW, where the mosque as a center of worship and civilization. a place to discuss many things, about religion and the problems of the people to find a solution. In the Qur'an at-Taubah verse 18, Allah swt says:

It means: 'Only those who prosper the mosques of Allah are those who believe in Allah and the Day Later, and continue to establish prayers, pay zakat and not be afraid (to anyone) other than to Allah, so they are the people who are expected people who got a clue'.

Village communities in general have a simple view. The most important thing in life is the availability of clothing, food and shelter, even to a minimum. Though society is an important element of the state in development. Development (development) is often synonymous with physical construction, construction of bridges, office buildings and other physical facilities. Development is identical to the process of planned change, or improvement of conditions for the better (Anwas: 2014). Development is an effort to achieve progress for mankind. Development can be interpreted as an effort to improve the quality of life for the community, which is supported by the central and regional government both physically and non-physically. Researchers see that development problems can be approached in terms of utilizing local results to improve the economic prosperity of the mosque-based local community.

\section{RURAL COMMUNITY}

Karanganyar Lor has two Community Associations (RW) and 16 Neighborhood Associations (RT) with a population of approximately 1263 people. With different economic groups and professions. The majority of the people of Dusun Karanganayar Lor work as farmers and farm laborers $(80 \%)$, entrepreneurs or traders and entrepreneurs $(15 \%)$, with the remaining $5 \%$ working for the rest. Then the community education background is not graduating from school and graduating from elementary school (SD) as many as 120 people, 191 junior high school, 102 senior high school and there have been 13 graduates and graduates (13 Data sources: Head of Karanganyar Lor sub-village). There are several organizations run in 
Karanganyar Lor, namely youth clubs, family program group (PKK) and socio-religious organizations.

Karanganyar Lor community are Muslim. This area is equipped with worship facilities with 1 mosque, Baitussalam mosque and 4 mushallas scattered in the hamlet area. In religious activities, each RT has a group of tahlilan, yasinan, diba'an or sholawatan and manakiban which is held routinely every week. There are also activities in the Khataman Al Qur'an which are carried out every Friday. Besides that, the Wali pilgrimage is also held twice a year. The proceed of the guardian's pilgrimage activities are used to buy some items, such as; event tents, plastic chairs, and goats. Also finance other activities that are religious, halal bihalal.

From the results of the research, it is known that two things become interesting studies that can be explained. Namely aspects of the potential of natural resources of economic value and awareness of human resources (community) towards religion. Karanganyar Lor Village is an agricultural area that produces mainly vegetables and fruits, although there are also some people who work as craftsmen. Woven bamboo craftsmen for the needs of vegetable and fruit farmers. Second, the Karang Lor community, especially around the Baitussalaam mosque, has a good religious awareness because it has a love of mosques and prayer rooms, this is evidenced by the very good construction of the mosque. Also has 4 (four) musholla (small place of praying). The problem is the limited knowledge and experience of organizational management, financial management and marketing. So that later the focus of research-based community service will help provide training and coaching in these three aspects to be able to provide positive change. In order to empower the economy of the local community that is already running to become better and more competitive.

As previously explained, that Karangnongko Village, Poncokusumo Subdistrict, Malang Regency is far from urban areas, the majority of the people are religious as farmers, farm laborers and entrepreneurs. The vast agricultural land adds to the assets of life and natural beauty. The work program begins with mapping of various assets in an aspect according to the survey instrument guidelines. Later, the potential of the village can develop and improve the quality of the community in a sustainable manner. Various aspects that become a reference, such as improving and developing religious quality, improving and developing the economic and cultural quality of society.

\section{RESEARCH METHOD}

In the implementation of this Partipation Action Research (PAR), it uses two main sources: First, Primary sources. Sources are taken directly, by looking at the potential and problems that exist in the area. In this case the researcher interviewed the Karang Anyar Lor head (Kasun), community leaders, leader (Takmir) Baitussalam Mosque and Indonesian Moscue Bareu (DMI) poncokusumo. Second, secondary sources. data that has been processed into documents. This data was obtained not only from interviews and data from Karanganyar Lor Hamlet, Karang Nongko Village, Poncokusumo District, Malang Regency, but also come from data sources and other information that can be trusted.

Then data is collected simultantly, for the overall data collection and then analyzed immadiately. Data is collected from various sources are directly reviewed and confirmed at the data source for deepening, this is done continuously until no new things are found, then concluded. This conclusion needs feedback in order to get input from various parties to perfect an accurate conclusion-making effort.

This action research method is carried out by making the community the subject of research not the object of research. The community itself understands, seeks, finds and solves their own problems, whether they are social, economic, cultural, environmental and others. Researchers are limited to functioning as a companion who helps to solve their problems, with the hope that they will get used to dealing with all social problems and then try to solve them properly and usefully. The process of their active and joint involvement in solving each problem is a major contribution in this action research process.

From the results of research on objects in this action research, it is known that two things become interesting studies that can be explained. Namely aspects of the potential of 
natural resources of economic value and awareness of human resources (community) towards religion. Karang Anyar Lor is an agricultural area that produces mainly vegetables and fruits, although there are also some people who work as free worker or part time. Woven bamboo craftsmen for the needs of vegetable and fruit farmers. Second, the Karanganyar Lor community, especially around the Baitussalaam mosque, has a good religious awareness because it has a love for mosques and prayer rooms. This is evidenced by the construction of a very good mosque. Also has had 4 musholla. The problem is the limited knowledge and experience of organizational management, financial management and marketing. So that later the focus of research-based community service will help provide training and coaching in these three aspects to be able to provide positive change. In order to empower the economy of the local community that is already running to become better and more competitive.

\section{a. Theory of Society}

\section{THEORITICAL DISCOURSE}

Society is a collection of so many individuals-small or large-bound by a unit, custom, rite or specific law, and live together (Shihab, 2013: 421). Then there are those who categorize that community with community which means 'local community', which shows a citizen of a village, city, ethnicity, or nation. If members-

Although the Qur'an is not a scientific book - in its broadest understanding - the Muslim holy book has a lot to say about society. According to Shihab (2013), because the main function of the holy book is to encourage positive changes in society, or in the terms of the Qur'an: litukhrijannaas minazh-zhulumaati ilan nur (removing humans from complete darkness into bright light). In line with the function of the holy book, this dedication also seeks to encourage the community to change themselves towards a better, prosperous physical and spiritual life. Although a change that certainly requires a process that is not short. At least with the change in mindset of the community to be more towards positive progress is the main capital to realize these noble ideals.

Local people who have permanent and permanent residences, according to Soekanto and Sulistyowati (2013), usually have strong ties of solidarity as a result of the unity of their residence. Indeed in modern society, due to technological developments in telecommunications equipment, the ties to residence are somewhat reduced, but on the contrary it is increasingly expanding the area of local communities. In essence, local communities function as benchmarks to strengthen the relationship between social relations with certain regions. As an example, how strong outside influence is in agriculture in rural areas of Poncokusumo, about more efficient planting methods, the use of supporting fertilizers and so on, rural communities will tend to maintain traditional methods, namely the relationship with the land that provides them with a source of life.

Besides the existence of a solidarity bond between the local community there is also a need for a feeling of mutual need and developing the region, because with this attitude this will be able to form a stronger community. These feelings are called 'community sentiment', which have elements such as; affectionate, dependent, and need each other. Furthermore, sociologically, this local community can be seen from several criteria, first; population, second; area, wealth and population density in rural areas, third; special functions of the local community towards the whole community; and fourth; the relevant local community organizations (Soekanto and Sulistyowati: 2013).

In modern society, there are rural communities and urban communities. Rural communities have closer and deeper relationships than urban communities that tend to be individualistic. The life systems of village communities are usually grouped on the basis of a family system. The main villagers' livelihoods are from agricultural products. Off-farm jobs are merely an additional, or part-time result. Even though agriculture is a main element of rural community income, the way they are implemented is still very traditional. Traditional and less efficient farming methods they still use, because mechanization in agriculture is not yet known. Usually they farm solely to make ends meet and not for sale. This method of farming is 
commonly referred to as subsistence farming. They feel satisfied if the family's needs are fulfilled (Soekanto and Sulistyowati, 2013: 137).

When viewed from the standpoint of government, in rural areas, the relationship between the authorities and the people take place unofficially. Everything is done by deliberation. Because there is no clear and clear division of labor, a village authority has many positions and roles that are difficult to separate or differentiate. Even in remote areas, it is very difficult to distinguish the position and role of a village head, as well as being the leader of the village government as well as parents or traditional leaders who are always asked for advice, support and guidance on various interests. In essence, everything is centered or centralized in the village leader. It is different from cities, where everything has been clearly and clearly stipulated in the division and function of a leader.

\section{b. Theory of Community Empowerment}

After describing the community's understanding and characteristics, a strategic empowerment for rural communities will then be presented. Where the emphasis is on empowering local potential, especially the economic potential of the region. As according to Anwas (2014) the potential that can be developed in the community consists of the potential possessed by individuals, the potential of the group, and also the potential possessed by nature, social and culture that exists around the area of their residence. Every individual has different needs and potentials. The potentials of individuals who are developed tend to vary, as do groups and between groups. Another case with the potential for areas that have similarities for individuals in the region.

Furthermore Anwas (2014) argues, the development of natural potential or natural resources must be based on processing the potential of local resources in the industrial structure. Activities such as exploitation of natural resources which are sold directly in raw conditions to the market can be difficult to encourage community independence. Before it should be sold, the potential of these local resources should be processed into semi-finished goods or attempted to become finished goods. Then for processing into semi-finished or finished goods requires quality human resources (HR) or competence in the field. In practice improving the quality of human resources in the community is not easy. This is related to habits that tend to have been entrenched hereditary. Therefore there is a need for self-awareness efforts, that each individual has the potential that can be developed. Then education, training, coaching or mentoring activities need to be carried out gradually and continuously.

Changing habit in communities to process natural resources to become semi-finished or finished goods is very beneficial. According to Anwas (2014), the benefits of developing quality human resources include; First, the value of the finished or semi-finished commodity will be far more valuable. Second, reduce unemployment because employment increases. Third, the ability and skills of the community will increase. Fourth, public awareness of the importance of education will increase along with market demands and developments. Fifth, the quality of life and welfare of the people will gradually increase along with the development of their abilities, skills and income. And sixth, the community becomes independent and prosperous.

\section{IMPLEMENTATION}

With managerial training that has not been organized, we will manage and assist in making the Karanganyar village community around the Baitussalam mosque provide higher economic value for the community. So that the income obtained can be arranged more managerially to become a professional business. Existing agricultural centers are expected to be able to run with professional managerial. In addition to the form of managerial activities that will be carried out in the hope that the industrial center will become professional and provide economic added value to the community, namely assistance in preparing financial reports or can be said with financial management. Financial management can be interpreted as management of financial functions. Broadly speaking, company functions can be grouped into four functions, namely: Marketing functions, financial functions, production functions, and personnel functions (Hanafi: 2010). 
As a miniature of an organization, the people in Karanganyar Lor village are included in it, can be categorized as a non-profit organization. That is a social organization that prioritizes the benefit of groups rather than individuals. Even if there are benefits, it will be enjoyed together. With the characteristics of rural communities who uphold togetherness they will try to advance the region together. Only the obstacles of knowledge and experience in economic development still need to be developed. So the focus of this service activity is training and coaching in the fields of management, financial reporting and materials about marketing. With the hope that it will provide insights and solutions to the marketing problems of agricultural products experienced by Karanganyar Lor farmers. Where so far only rely on foreign buyers or large capital without knowing the market price. So they often suffer losses because they fall victim to the price game of middlemen. In addition, creative efforts will emerge to innovate new forms of business based on local natural resources.

In developing the local economy there must be financial management. The management or financial management includes activities, first; Financial planning. With the understanding that financial planning is a process to achieve one's financial goals through integrated financial management planned. Internally and externally.

Second, financial management. Activities related to how to obtain and use and manage company finances to achieve the main objectives of the company. Then as for financial management activities, namely planning, organizing (including raising funds with the smallest possible cost, investing funds owned and sharing the results of profits in the form of dividends). Doing. Control. Financial institutions or financiers will lend or invest their funds, if the borrower, the applicant has a trusted business profile also has a very promising prospect. Business profile here by showing regular and accountable financial records. While the prospects that are easy to get an injection of funds at this time are those who are engaged in businesses based on food, crafts and information-technology (IT). Financing applies the 5C principle, namely, character, capacity, capital, collateral and conditions. And plus the 7P principle, are personality, party, purpose, prospect, payment, profitability, and protection.

Third, writing financial reporting. Businesses that do the writing carefully, regularly and continuously will make it easy for business actors to control their finances. Besides that, it will be a consideration for investors or financial institutions to invest their funds in entrepreneurs whose financial report are good and accountable.

The experience is the best teaching without proper knowledge and treatment will be ineffective and the benefits will be temporary. As an example of how the development of dragon fruit, tomatoes and so on are plummeted in the market due to over production, where without careful planning is still emotional, seasonal, resulting in not a huge gain but often loss. Because the existence of a farmer cooperative in Karanganyar Lor can be a solution for handling agricultural problems for the majority of farmers. That way it will provide economic and managerial benefits. Related parties, stakeholders, will easily provide technical and nontechnical assistance in an effort to improve the quality of life through the organization.

\section{SCIENTIFIC DYNAMIC}

By this empowerment, many things can be discussed and developed. Theoretically, as expressed by Ibn Khaldun, the father of the social sciences of the World, who said that human are by nature political and that they can not be separated from a kind of social organization which in philosophical terms is called metropolis (Madina). This is the social organization ('umran). God made humans so that they had to get food to survive. Although they are given the potential to get this food, they are unable to meet their individual needs. They are encouraged to cooperate with each other to meet the needs of many people can be met (Alatas, 2017: 76). Simply put, Ibn Khaldun, explained that human society is undoubtedly (sunnatullah), humans are affected physically, psychologically and socially by the physical environment and humans are connected with the spiritual world, which is beyond sensory perception (Alatas: 2017)

In implementing an idea or ideas for the formation of a society that is empowered and independent above will not run smoothly as expected, of course it will face many challenges. 
According to Bryson (2005), there are at least four challenges faced. First, the human problem is management of attention and commitment. The attention of key people must be focused on issues, decisions, conflicts and policy preferences at key places in the organizational process and hierarchy. Second, the problem with the process is the management of strategic ideas into good currency. Unconventional wisdom is changed to conventional wisdom. Third, the structural problem is the management of part and overall relationships. Internal and external environment must be a very beneficial relationship. The fourth is an institutional problem is the implementation of transformative leadership. This is the most difficult problem, without the support of transformative leadership with accommodative and visionary character, it will be difficult to realize strategic planning to achieve expectations. Through institutional transformation, this can be solved. Such a transformation would not occur without strong leadership.

Ibnu Khaldun's previous explanation, that humans are naturally connected to the spiritual world, which is beyond sensory perception. That is, humans need the presence of religion in the dynamics of their lives. Islam teaches the balance of life, where through the holy book, which is in the first letter, al-Alaq verses $1-5$, so that humans read the universe by always remembering the Creator, Allah swt. In line with the context of community empowerment, the element of the mosque cannot be released and the role of the mosque is very important to the dynamics of the community from the past as well as now.

The word mosque is repeated twenty-eight times in the Qur'an. The mosque is taken from the origin of the word sajada-sujud, which means obedient, submissive and submissive with respect and reverence. In everyday terms, a mosque is a building where Muslims pray. However, because the root contains the meaning of submission and obedience, according to Shihab (2013), the essence of a mosque is a place to carry out all activities that contain obedience to Allah swt. Therefore, the Qur'an surat al-Jin verse 18, for example, asserts that, It means: "... and indeed the mosques belong to Allah. Then do not worship anyone in it beside (worshiping) Allah "(Surah Al-Jin: 18).

If associated with this earth, the mosque is not just a place of prostration or a means of worship, a mosque is built on the basis of devotion, but the mosque is a place to carry out all human activities that reflect adherence to Allah Almighty. That way, the mosque becomes a base for Muslims to leave, as well as the port where they anchor. Therefore the Nabawi mosque in Madinah plays a variety of functions. Namely as a place; worship, consultation and communication, teaching and learning process, social compensation, military training, treatment of victims of war, peace and disputes court, receiving tofu, capturing prisoners and centers for information and religious defense (Shihab: 2013).

The mosque of the past can function widely because of other reasons: First, the state of the past which still holds fast to the values, norms and the soul of religion. Secondly, the ability of mosque coaches to link social condition and community need with mosque descriptions and activities. And third, the manifestation of government is carried out in the mosque, both individuals of government leaders who become imam or preachers or in the mosque's rooms which are used as a place for governance activities (shura) (Shihab: 2013).

Once the importance of the role of the mosque, then this community service, making the mosque as the basis of all community activities. The magnificent Baitussalam Karanganyar Lor Poncokusumo Mosque reflects, not only as a place of worship but as a place where community activities are centered. The community is so enthusiastic when it comes to the mosque, it can be seen even though the houses of the residents are so simple but a mosque that is very good for a rural size is a community self-help. Moreover, coupled with there are 4 (four) mushollas that are no less beautiful. Communities gather, deliberate and decide on community activities starting from the mosque. The community realizes that there is no end to all world activities, by making the mosque as a place to reflect all of its life activities, it becomes balanced in living life. Only what needs to be developed is the quality of the resources of the mosque, both the management and the youth or youth of the mosque. To have a variety of knowledge, both religious and conventional, especially about mosque management and financial management. Zakat, infaq 
and shodaqoh, which have been running routinely once a year, have improved their quality to be more developed in accordance with Islamic sharia. Because it has a very broad economic impact. Community empowerment can be started by giving meaning and developing the excavation and utilization of these sources. With so the function of the mosque more and more contribute to the local community.

With the explanation above, it also means that the mosque can be the center of the formation of the mankind unity (ummah waahidah) in the context of monotheism. A new hope in the middle of a complex and plural society, to build an ideal society or civil society based on a mosque. Where it not only revolves around the routine activities of worship (mahdloh) but, it has developed to a promising scope that is on the economic aspect (mu'amalah). Namely by making the mosque as a center for community economic development (Nugraha: 2010).

\section{EMPOWERMENT THEORY}

Besides relating to the theory of getting to know the community and its characteristics, which have been presented previously. Researchers also learn about empowerment theory. Empowerment is a process to provide power to the weak (powerless) and reduce power (disempowered) to those who are too powerful so that the balance occurs. It can also be interpreted that empowerment is a way by which the people, organizations and communities are directed to be able to dominate or rule over their lives (Anwas; 2014).

The definition of empowerment above emphasizes the aspects of delegating authority, power, and the influence or transfer of power to individuals or society so that they are able to organize themselves and their environment according to their desires, potentials, and abilities. In empowerment, there is coaching, training and encouragement which is an educational process in an effort to improve the quality of individuals or communities so that they able to regulate themselves and their environment in accordance with their desires, potential and needs (Anwas: 2014).

In community there are certainly various obstacles. There are four challenges faced as stated by Bryson (2005). First, human problems, which need management attention and commitment. The attention of key people must be focused on issues, decisions, conflicts and policy preferences at key places in the organizational process and hierarchy. Second, the problem with the process is the management of strategic ideas into good currency. Unconventional wisdom is changed to conventional wisdom. Third, the structural problem is the management of part and overall relationships. Internal and external environment must be a very beneficial relationship. The fourth is an institutional problem is the implementation of transformative leadership.

The synergy commitment needs to be carried out, working together to achieve the expected goals and the integrity or joint commitment of various parties. First, the place for community activity to change by learning and following up. Second, the stakeholder holder of a figure or government, to confirm and facilitate what is needed by the community.

\section{DISCUSSION}

Based on the action research approach in carrying out community some data and facts can be described as follows; First, Planning, which is mapping the condition of the Karanganyar Lor Village, Poncokusumo District, Malang Regency. Karanganyar Lor has two Community Associations (RW) and 16 Neighborhood Associations (RT) with a population of approximately 1263 people. With different economic groups and professions. The majority of the people of Karanganayar Lor village are working as farmers and farm laborers $(80 \%)$, entrepreneurs or traders and entrepreneurs (15\%), with the remaining 5\% working for the rest. Then the background of community education is not graduating from school and completing elementary school (SD) as many as 120 people, 191 junior high school, 102 senior high school and there have been 13 graduates or graduates there are 13 people (Data source: Head of Karanganayar Lor). There are several organizations run in Karanganyar Lor, namely youth clubs, PKK and socio-religious organizations. 
Second, by looking at the general map of the Karanganyar Lor area above, an action was taken, namely carrying out the planned efforts in the Karanganyar Lor Poncokusumo. Namely approaching, discussing the potential of natural resources, human resources in East Karanganayar and have a strategic economic impact on the community. After being discussed and found the problem then find a solution to the solution that is by holding training and community economic development based on local potential.

Third, during the implementation of the activity, the researcher while observing the enthusiasm of the participants of the training and coaching at the Mosque. They are motivated to implement what is conveyed, even though it will require a mentoring process. By this situation carefully listened and tried to find a solution about what has not been implemented yet, then fix it, of course, taking into account the advantages and disadvantages.

Fourth, conduct feedback, which evaluates the strengths, weaknesses and successes that have been achieved, and see to what extent the problems encountered can be resolved. In this case an analysis of strengths, weaknesses, opportunities and threats abbreviated to SWOT can be offered. Where the formulation of strength is to see the potential that exists in the village of Karang Anyar Lor. Henceforth, it is maximized to become a potential of natural resources and solid human resources economically valuable. The vast area of agricultural land supported by educated resources is an important capital to make this Karanganyar Lor village empowered and independent. Then is the weakness, where the Karanganya Lor still applies traditional methods in managing its agricultural land and has not tried to use modern technology in order to get more efficient and effective results. In addition, innovation to look for other economic alternatives to sustain life has not yet been created, aside from capital reasons as well as courage to start. Next, the opportunity presented was like a good road, close to the highway for fast transportation access. Close to the center of the crowd, such as markets, sub-district or government centers, schools, tourism facilities and airports. If the opportunity is utilized properly, it will be very beneficial both in terms of economic and interest relations. Finally, arrived at the threat aspect. Leaving the condition of the region in a state of stagnation or road in place, not developing in a long time will be a threat in the future. Concern and motivation that are not built on continuously, especially after getting training, cause a decrease in enthusiasm for learning and practicing for maximum results.

\section{EXPECTATION}

In carrying out research-based community service in Karang Anyar Lor Hamlet, it has indeed been done in accordance with the provisions of the time. Because the time is so short of course many things need to be refined and followed up on. As excavation of existing potential is further developed. Modernization in terms of agricultural ecotourism needs to be initiated, the area and its main livelihood is agriculture. You could say this area is a center of agricultural. The term horticulture itself comes from the Latin language, hortus means garden and culture itself means farming. So in general, horticulture is all farming activities such as vegetables, fruits, or ornamental plants, where the land (garden or house yard).

With this training the researcher becomes aware of what is already and When people have started to know what they should be doing it will become easier to develop. Because the essence of empowerment is to give a mandate or power to individuals or communities to explore, manage, develop the potential of their territories according to their abilities. All of them depend on the will, sincerity and commitment of the local community to make them more empowered and independent. While researchers or service teams from tertiary institutions (or whatever institutions they come from) are only empowerers, coaches who are very limited in their time and abilities. In this case, the role of stake holder or regional stakeholders, the government of Poncokusumo sub-district of Malang is highly expected. Because they have human resources and capital through local budgets to provide technical and non-technical assistance.

Effective and efficient community empowerment needs to be socialized. The government seems rather difficult to provide assistance to the people even though they really 
need it. In the observation of stakeholders, the community can only ask for and spend a budget without making a significant contribution to the government. Therefore we need an effective strategy in community empowerment. The Funding assistance is important, because it is the main capital for the sustainable effort of community empowerment. But more important is how the sustainability and development of the empowerment process. Provision of capital and ongoing coaching would be very necessary. If the training runs smoothly and as needed, the community will not think about material assistance anymore. Because of the successful empowerment is when the community can be independent and prosperous.

Based on the focus of this research, namely the empowerment of regional (local) -based economy, together with stakeholders from the local government developed the concept of horticultural-based ecotourism in the Karang Anyar Lor region. A lot of land can be utilized in order to make the area one of the centers of agricultural production that is not only of economic value but also can attract consumers to enjoy the natural beauty around the famous poncokusumo region. They need assistance in managerial, organizational, financial management and marketing. While the government is expected to assist administration, financing and sponsorship. With the synergy of the triad consistently and simultaneously it is believed to be able to produce effective and efficient, efficient and efficient empowerment. Hopefully that hope comes true, may Allah grant it. Aamiin

\section{CONCLUSION}

Masjid or mosque-based community economic empowermant uses active research or participatory action research (PAR). Then the mentoring by the researcher is in the context of synergizing between fieldwork and mentoring that provides great benefits to the local community.

Karanganayar Lor is sub of Karang Nongko Village, Poncokusumo District, Malang Regency, east side of Malang town. Karanganyar Lor is one of 5 sub-areas in Karang Nongko Poncokusumo, which has the potential of horticultural agriculture (vegetables and fruits), mutual cooperation and religious characteristics.

The condition of the Karanganyar Lor community has two Community Associations (RW) and 16 Neighborhood Associations (RT) with a population of approximately 1263 people. With different economic groups and professions. The majority of the people of Karanganayar Lor work as farmers and farm laborers (80\%), entrepreneurs or traders and entrepreneurs $(15 \%)$, with the remaining 5\% working for the rest. Then the background of community education is not graduating from school and completing elementary school (SD) as many as 120 people, 191 junior high school, 102 senior high school and there have been 13 graduates or graduates there are 13 people (Data source: Head of Karanganayar Lor). There are several organizations run in Karanganyar Lor, namely youth clubs, PKK and socio-religious organizations.

The strategy is the empowerment of a local economy based on mosques in the area around the Baitussalam Mosque of Karanganyar Lor, Karang Nongko Poncokusumo Malang. This mosque-based empowerment by providing training and coaching in general management, financial reporting or financial management and marketing.

The results of research hope that it can provide understanding and change to the community in the Baitussalam Mosque in economic terms to the next better direction. With the increase in the economy the community will remain religious, continue to balance between the interests of the afterlife and the world (hablumminalloh and hablumminannas) to get pleasure from Allah swt. 


\section{BIBLIOGRAPHY}

Al Qur'anul Karim dan terjemahannya

Alatas, Syed Farid. 2017. Ibnu Khaldun, Biografi Intelektual. Jakarta: Mizan

Anwas, Oos M. 2014. Pemberdayaan Masyarakat di Era Global. Bandung: Alfabeta

Bryson, John M. 2005. Perencanaan Strategis Bagi Organisasi Sosial. Penerjemah oleh Miftahuddin. Yogyakarta: Pustaka Pelajar

Hanafi, Mamduh, M. 2010. Manajemen Keuangan. Yogyakarta: BPFE

Nugraha, Firman. 2010.Transformasi Umat Islam Berbasis Masjid. Jurnal Tatar Pasundan Volume IV Nomor 11.

Shihab, M. Quraish. 2013. Wawasan Al-Qur'an. Bandung: Mizan

Soekanto, Sarjono dan Budi Sulistyowati. 2013. Sosiologi Suatu Pengantar. Jakarta:

RajaGrafindo Persada

Website:hhtp:www.tipsdokter.site/2019)

Website:www.pengertianku.net/2019

Website:id.m.wikipedia.org 